\title{
Pelatihan Strategi Komunikasi Pemasaran untuk Meningkatkan Pangsa Pasar Produk Dodol di Daerah Pasar Bengkel Kabupaten Serdang Bedagai
}

\author{
Training for Marketing Communication Strategies to Improve Dodol Product Market Share \\ in the Bengkel Market Area of Serdang Bedagai District
}

\author{
${ }^{1 *}$ Arief Marizki Purba, ${ }^{2)}$ Adil Arifin, ${ }^{3)}$ Fernanda Putra Adela, ${ }^{4)}$ Alwi Dahlan Ritonga \\ ${ }^{1)}$ Program Studi Ilmu Komunikasi, Fakultas Ilmu Sosial dan Ilmu Politik \\ ${ }^{2,3,4)}$ Program Studi Ilmu Politik, Fakultas Ilmu Sosial dan Ilmu Politik \\ Universitas Sumatera Utara \\ J1. Dr. A. Sofian No.1A Medan \\ *email: alwiedahlan@gmail.com
}

DOI:

\subsection{5/jppm.v5i1.8363}

\section{Histori Artikel:}

Diajukan:

24/08/2020

Diterima:

$05 / 04 / 2021$

Diterbitkan:

$14 / 04 / 2021$

\section{ABSTRAK}

Pelatihan dan sosialisai diberikan kepada masyarakat yang dalam hal ini adalah para pedagang produk dodol di Dusun II Pasar Bengkel Kabupaten Serdang Bedagai. Dalam pelatihan ini, pihak mitra diberikan materi-materi pokok (modul) tentang strategi komunikasi pemasaran yang baik, benar dan sesuai untuk di implementasikan di sana. Pihak mitra lebih mampu mengembangkan potensi pangsa pasar melalui pendayagunaan media-media online sehingga tidak hanya terpaku dan bergantung kepada para pengguna jalan saja. Dengan demikian maka mitra lebih paham dan mengerti tentang langkah-langkah yang bisa diambil untuk mengatasi permasalahan yang sedang mereka alami. Target yang ingin dicapai melalui pengabdian ini adalah: (1) Jangkauan pangsa pasar para pedagang produk dodol di Dusun II Pasar Bengkel lebih luas dan meningkat. (2) Kelompok mitra terampil dalam mempromosikan produknya melalui toko-toko online dengan mengandalkan berbagai media sosial yang ada saat ini. (3) Kelompok mitra lebih teredukasi dalam mengembangkan usahanya melalui strategi komunikasi pemasaran yang telah diberikan nantinya. (4) Kelompok mitra mampu meningkatkan nilai jual produk dodol melalui beberapa keterampilan dan bantuan yang diberikan nantinya. (5) Dengan terlaksananya pelatihan dan sosialisasi strategi komunikasi pemasaran ini, maka diharapkan dapat meningkatkan taraf hidup kelompok mitra sehingga usaha produk dodol tetap lestari dan berkelanjutan.

Kata kunci: Komunikasi Pemasaran; Usaha Produk Dodol; Pengelolaan Usaha

\begin{abstract}
Training and socialization were given to the community, in this case the traders of dodol products in Dusun II Pasar Bengkel, Serdang Bedagai Regency. In this training, partners are given basic materials (modules) on a good, correct and appropriate marketing communication strategy to be implemented there. Partners are better able to develop potential market share through the use of online media so that they are not only fixated and dependent on road users. Thus, partners will better understand and understand the steps that can be taken to overcome the problems they are experiencing. The targets to be achieved through this dedication are: (1) The market share of the dodol merchants in Dusun II Pasar Bengkel is wider and increasing. (2) The partner group is skilled in promoting its products through online shops by relying on various social media that exist today. (3) The partner group is more educated in developing its business through the marketing communication strategy that has been given later. (4) The partner group is able to increase the selling value of dodol products through several skills and assistance provided later. (5) With the implementation of training and dissemination of this
\end{abstract}


Arief Marizki Purba, Adil Arifin, Fernanda Putra Adela, Alwi Dahlan Ritonga

Pelatihan Strategi Komunikasi Pemasaran untuk Meningkatkan Pangsa Pasar Produk Dodol di Daerah Pasar Bengkel Kabupaten Serdang Bedagai

marketing communication strategy, it is hoped that it can improve the standard of living of partner groups so that the dodol product business remains sustainable and sustainable.

Keywords: Marketing Communications, Dodol Product Business, Business Management

\section{PENDAHULUAN}

Pemberdayaan Usaha Mikro Kecil dan Menengah (UMKM) adalah hal yang sangat penting untuk dilakukan. Hampir semua sepakat tentang hal tersebut, karena UMKM secara nyata memang mampu bertahan dan menjadi bagian dari penggerak dan sekaligus penopang ekonomi negara. Pada tahun 2011, UMKM memiliki peran besar terhadap penerimaan negara dengan menyumbang 61,9 $\%$ penerimaan Produk Domestik Bruto (PDB) melalui pembayaran pajak (Sudaryanto, Ragimun, \& Wijayanti, 2013, p. 2). Selain itu, UMKM mampu menyerap tenaga kerja sebesar 99,45\% dan jumlah unit usaha yang terlibat sangat besar yaitu pada kisaran $99,84 \%$ dari seluruh usaha yang ada lalu jumlah nilai eksport totalnya cukup signifikan dengan angka capaian sebesar 18,72\% (Niode, 2009).

Dampak positif yang dihasilkan oleh adanya UMKM begitu besar. Keberadaannya mampu menjadi pemecah sebagian permasalahan yang sedang dihadapi oleh negara. Kuncoro (2007) mengatakan bahwa industri-industri kecil seperti UMKM memiliki peran positif yang cukup besar karena mampu menyediakan kesempatan kerja, membantu memecahkan masalah pengangguran, pemerataaan distribusi pendapatan dan pengurangan jumlah kemiskinan.

Akan tetapi, disamping besarnya peran positif yang disumbangkan oleh sektor UMKM terhadap pembangunan ekonomi negara, terdapat juga beberapa tantangan dan masalah yang masih menjadi penghambat kemajuan sampai saat ini. Menurut Pramiyanti (2008) dalam Niode (2009), terdapat dua permasalahan utama yang dialami oleh UMKM secara umum yaitu permasalahan finansial dan nonfinansial (organisasi manajemen). Karena pelatihan ini hanya akan menyentuh aspek nonfinansial (organisasi manajemen), maka permasalahan yang akan di elaborasi dalam proposal ini adalah permasalahan nonfinansial tersebut. Permasalahan non finansial tersebut diantaranya ialah: a) kurangnya pengetahuan atas teknologi dan quality control yang disebabkan oleh kurangnya kesempatan mengikuti perkembangan teknologi serta minimnya pendidikan dan pelatihan; b) kurangnya pengetahuan akan pemasaran yang disebabkan oleh terbatasnya informasi yang dapat dijangkau oleh UMKM mengenai pasar, disamping keterbatasan kemampuan UMKM untuk menyediakan produk/jasa yang sesuai dengan keinginan pasar; c) keterbatasan sumber daya manusia (SDM) serta kurangnya sumber daya untuk mengembangkan SDM; dan d) kurangnya pemahaman mengenai keuangan dan akuntansi.

Pelatihan yang dilakukan secara khusus membahas mengenai aspek pemasaran. Sebagaimana telah disinggung di atas bahwa pemasaran menjadi salah satu permasalahan tersendiri yang dialami oleh UMKM. Berdasarkan data yang telah dirilis oleh Badan Pusat Statistik (BPS), terdapat beberapa jenis kendala yang dialami oleh UMK beserta persentasenya yaitu posisi pertama tentang adanya pesaing sebanyak 60,53\%; kedua tentang permodalan/likuiditas 60,14\%; ketiga tentang pemasaran $33,04 \%$; keempat bahan baku/barang dagangan 14,36\%; kelima tentang infrastruktur $7,79 \%$; keenam tentang tenaga kerja 4,41\%; dan seterusnya (Tusianti, Prihatiningsih, \& Santoso, 2019). Berdasarkan data tersebut, dapat dilihat bahwa persoalan tentang pemasaran menjadi masalah yang cukup besar dirasakan oleh kalangan pengusaha UMKM.

Pasar Bengkel adalah sebuah pusat oleh-oleh atau jajanan dan sering disebut sebagai wisata kuliner khas Kabupaten Serdang Bedagai. Pasar Bengkel berada di kawasan Jalan Lintas Sumatera Utara (JALINSUM), lebih tepatnya berada di Dusun II Desa Bengkel, Kec. Perbaungan, Kabupaten Serdang Bedagai, Provinsi Sumatera Utara. 
Dodol dengan varian rasanya merupakan produk yang paling terkenal di kawasan ini sehingga sering juga disebut sebagai Pasar Dodol. Potensi usaha dodol yang ada di kawasan ini cukup bagus dan sangat terkenal. Terdapat beberapa UKM dodol yang berdiri di kawasan ini diantaranya UKM Dodol Sri Rezeki, UKM Dodol Anugerah, UKM Dodol Sejahtera, dan lain-lain.

Akan tetapi, sebagaimana yang telah diterangkan di atas, usaha dodol juga mengalami permasalahan. Terkhusus di kawasan ini, permasalahan yang paling menonjol ialah terkait dengan adanya penurunan pangsa pasar atau konsumen produk dodol tersebut. Penurunan ini semakin terasa semenjak Tol Medan - Tebing Tinggi resmi dibuka oleh pemerintah pada tahun 2017. Selama ini, pangsa pasar yang diandalkan adalah para pengemudi yang melintas di Jalan Lintas tersebut. Ketergantungan pangsa pasar ini menimbulkan imbas yang serius bagi para pengusaha ketika pengemudi yang melintas semakin sepi. Sebagian pedagang telah melakukan pengurangan omset hingga mencapai 50-80 persen dari pendapatan sebelum tahun 2017 hingga dibukanya jalan Tol. Bahkan, dari sekitar 80-an jumlah kios dodol yang ada selama ini, sebanyak 40-an kios kini terlihat sudah tutup sebab keuntungan yang turun drastis (Dnaberita.com, 2019).

Untuk itu, perlu dilakukan upaya memperluas dan meningkatkan pangsa pasar produk dodol di kawasan Pasar Bengkel tersebut. Bagaimana tidak, jika pangsa pasar rendah maka daya jual produk juga akan rendah dan secara langsung juga akan menyebabkan penurunan pendapatan. Jika pendapatan rendah, bisa saja para pengusaha berhenti berproduksi dan akibatnya produk dodol akan hilang sama sekali. Dengan demikian, untuk mengatasi persoalan minimnya pangsa pasar, maka upaya yang harus dilakukan ialah dengan memperluas jangkauan pangsa pasar melalui pemasaran yang baik. Oleh karenanya, maka perlu dilakukan pembekalan dan pendampingan tentang Strategi Komunikasi Pemasaran terhadap mitra di lapangan.
Menurut Kotler dan Amstrong (2008) dalam (Hamid, 2016), strategi pemasaran modern secara umum terdiri dari tiga tahapan yaitu: segmentasi pasar (segmenting), penetapan pasar sasaran (targeting), dan penetapan posisi pasar (positioning). Komunikasi pemasaran pada dasarnya merupakan proses penyampaian informasi produk dari produsen kepada konsumen (Iriantara, 2014). Komunikasi pemasaran akan berangkat dari perencanaan komunikasi pemasaran terpadu yang kemudian perusahaan mengkomunikasikan konsep pemasaran kepada konsumen. Elemen-elemen komunikasi pemasaran terpadu terdiri dari iklan, penjualan personal, promosi penjualan, hubungan masyarakat dan publisitas, pemasaran langsung dan pemasaran interaktif/internet (Morissan, 2015 dalam Rachmawati, 2018).

Permasalahan yang paling mendasar dan mencemaskan bagi kelompok mitra ialah tentang adanya penurunan pangsa pasar yang sangat drastis. Sebagaimana yang telah dijelaskan di atas, permasalahan ini bermula semenjak Tol Medan - Tebing Tinggi mulai beroperasi pada tahun 2017 lalu. Semenjak itu, konsumen produk dodol berangsur-angsur semakin menurun sehingga beberapa kios bahkan mengalami gulung tikar. Sebagian pedagang telah melakukan pengurangan omset hingga mencapai 50-80 persen dari pendapatan sebelum tahun 2017 hingga dibukanya jalan Tol. Bahkan, dari sekitar 80-an jumlah kios dodol yang ada selama ini, sebanyak 40-an kios kini terlihat sudah tutup sebab keuntungan yang turun drastis (Dnaberita.com, 2019). Fenomena ini sebenarnya menunjukkan bahwa pangsa pasar produk dodol di Pasar Bengkel terlalu bergantung hanya kepada pengguna jalan.

Selain itu, hal ini juga menunjukkan akan minimnya kemampuan para pengusaha dodol dalam mencari alternatif atau inovasi yang mampu untuk memecahkan persoalan pemasaran produk mereka. Sejauh ini mereka belum bisa meningkatkan dan meluaskan jangkauan pangsa pasar mereka ke segmentasi-segmentasi lain selain daripada pengguna jalan. Hal lain yang juga menjadi permasalahan adalah pemahaman yang minim di kalangan para pengusaha mengenai 
pengelolaan produk seperti proses pengemasan yang bagus dan kekinian sehingga daya tarik produk menjadi kurang di mata para konsumen. Oleh karena itu, pelatihan ini diharapkan mampu menjadi pemecah permasalahan yang sedang mereka alami saat ini.

Berdasarkan latar belakang di atas, maka tujuan pengabdian ini ialah untuk meningkatkan pangsa pasar pedagang produk dodol dengan cara memberikan pelatihan tentang strategi komunikasi pemasaran.

\section{METODE}

Metode pelaksanaan pengabdian dilakukan dengan cara membuat suatu pelatihan dan sosialisasi terhadap mitra/peserta yang berjumlah 33 orang. Kegiatan dimulai dengan melakukan survei awal ke lokasi mitra untuk mengetahui apa saja kendala dan permasalahan yang sedang dihadapi oleh mitra. Setelah mengetahui pokok-pokok permasalahan yang sedang dihadapi oleh mitra, maka selanjutnya Tim Pengabdi mendalami permasalahan tersebut untuk kemudian mencari solusinya melalui strategi komunikasi pemasaran yang berbasis kepada inovasi teknologi informasi.

Kegiatan pelatihan dilakukan dengan memberikan materi-materi yang telah disiapkan oleh Tim Pengabdi. Adapun materi yang disampaikan di antaranya ialah tentang pokok-pokok strategi komunikasi pemasaran, inovasi packaging, pelatihan penggunaan media sosial, pelatihan penggunaan marketplace. Dalam proses pelatihan pemateri menyelinginya dengan beberapa demonstrasi dan diskusi tanya jawab.

\section{HASIL DAN PEMBAHASAN}

Secara umum pencapaian dari pengabdian ini adalah telah terlaksananya kegiatan berupa pelatihan kepada mitra dengan menghadirkan peserta dari kalangan masyarakat dan pedagang dodol di Pasar Bengkel. Kegiatan ini diikuti oleh 33 peserta, terdiri dari kalangan masyarakat yang berprofesi sebagai pedagang dodol dan para aparatur desa yang kebetulan juga memiliki usaha dagang produk dodol. Kemudian terdapat juga beberapa kalangan mahasiswa yang sedang melakukan KKN di desa tersebut. Dari gambaran tersebut terlihat bahwa pengabdian ini diterima dengan sangat antusias di Desa Bengkel. Kegiatan pelatihan dilaksanakan pada hari Senin 10 Agustus 2020 bertempat di Balai Desa Kantor Kepala Desa Bengkel Jl. Pendidikan No. 184, Bengkel, Kec. Perbaungan, Kabupaten Serdang Bedagai. Kegiatan pelatihan dibuka oleh Alwi Dahlan Ritonga selaku Tim Pengabdian USU. Kemudian Kepala Desa Bengkel Indra Fajar dan Ketua BPD Azwar Guci, ST memberikan sambutan atas kedatangan Tim Pengabdian dan mengucapkan terima kasih atas terselenggaranya pelatihan tersebut. Setelah itu kemudian Ketua/Wakil Tim Pengabdian memberikan sambutan dan materi kegiatan yang meliputi: Pokok-pokok Strategi Komunikasi Pemasaran, Inovasi Packaging, Pelatihan Penggunaan Sosial Media, Pelatihan Penggunaan Marketplace. Dalam rangkaian proses pelatihan diiringin dengan praktik dan diskusi serta tanya jawab dengan peserta.

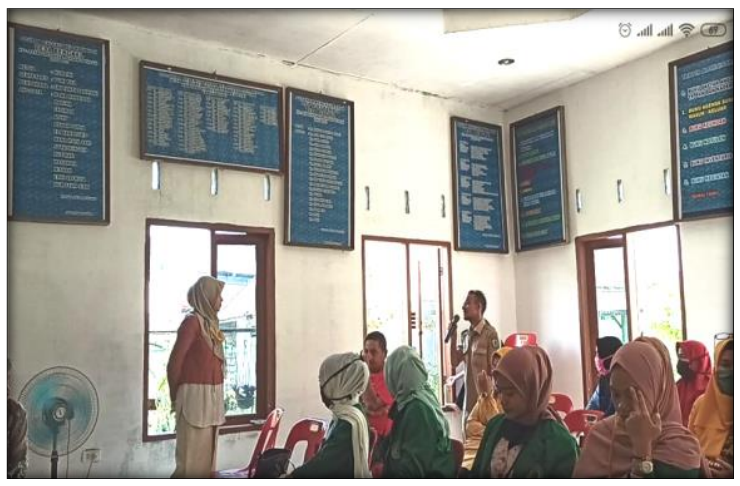

Gambar 1. Momen ketika peserta bertanya kepada pemateri

Hasil yang dicapai dari pengabdian dengan mitra di Desa Bengkel diantaranya bahwa para pengusaha produk dodol Pasar Bengkel menjadi sadar bahwa organisasi merupakan wadah yang sangat penting untuk menumbuhkan kesadaran kolektif antar sesama pedagang dodol. Ketika melakukan analisis di lapangan, tim pengabdian menemukan satu persoalan serius yang dihadapi oleh para pedagang yaitu berupa tidak adanya kekompakan antara sesama pedagang. Bahkan sangat sering terjadi 
persaingan yang tidak sehat diantara mereka sendiri. Padahal, dengan persoalan serius yang sedang mereka hadapi, kekompakan atau kolektivitas merupakan satu modal penting yang harus dimiliki dalam melakukan perjuangan terhadap pemerintah. Akan tetapi pada praktiknya, para pedagang hanya berjalan secara masing-masing dan tidak terhimpun dalam satu wadah organisasi. Berangkat dari permasalahan serius tersebut, Tim Pengabdian berupaya memberikan penyadaran secara serius terhadap para pedagang Pasar Bengkel. Dengan adanya proses penyadaran tersebut, Tim Pengabdian berhasil membuat para pedagang terstimulus untuk segera membuat satu wadah organisasi yang nantinya organisasi ini dapat menjadi satu modal perjuangan para pedagang untuk bisa memecahkan persoalan yang sedang mereka hadapi. Pada saat proses pelatihan berlangsung, Tim Pengabdian menyampaikan bahwa Tim akan bersedia untuk mendampingi para pedagang dalam proses pembuatan wadah organisasi tersebut.

Ketika sedang melakukan pelatihan, Tim Pengabdian menemukan hal yang cukup mengejutkan. Hal tersebut ialah bahwa hampir semua pedagang yang terlibat dalam pelatihan tersebut belum mengerti tentang potensi teknologi informasi dalam dunia usaha saat ini. Ringkasnya, mereka tidak tahu sama sekali bagaimana cara menggunakan akun-akun medsos seperti Facebook, Instagram, Twitter dan lain sebagainya. Hal ini memang dapat dimaklumi karena sebagian besar pedagang merupakan kalangan yang sudah tua sehingga mereka mengalami "kegagapan" dengan perkembangan teknologi yang demikian. Dengan upaya yang serius, Tim Pengabdian memberikan pelatihan dan penyadaran tentang pentingnya menggunakan inovasi teknologi dalam mengembangkan pangsa pasar di era modern ini. Respon positif muncul dari para pedagan, karena hal tersebut merupakan pengetahuan baru bagi mereka dan harus dijalankan. Dengan demikian, para pedagang dodol mendapatkan skill baru dalam mengembangkan usahanya.

Temuan lain yang didapat oleh Tim Pengabdian ketika sedang melakukan survei di lapangan adalah bahwa inovasi mengenai kemasan dodol masih kurang menarik. Kemasan produk dodol mereka kurang memikat karena tidak kekinian. Kemasan yang mereka gunakan tidak pernah berubah mulai dari zaman dahulu sampai saat ini. Berangkat dari permasalahan ini, maka Tim Pengabdian menganggap bahwa permasalahan kemasan juga menjadi poin penting yang harus diperhatikan jika ingin meningkatkan pangsa pasar. Terdapat keterkaitan yang kuat antara kemasan yang menarik dengan minat pembelian. Oleh karena itu, salah satu materi pokok yang Tim suguhkan ketika sedang melakukan pengabdian ialah mengenai pentingnya kreasi kemasan dalam menarik minat konsumen. Setelah memberikan konsepkonsep dan materi yang mampu meningkatkan minat peserta dalam mengubah kreasi kemasan, maka selanjutnya Tim memberikan masukan dan saran berupa inovasi-inovasi kemasan yang lebih kekinian. Berdasarkan pantauan Tim ketika sedang melakukan pelatihan, para peserta sepakat bahwa kemasan menjadi salah satu yang harus segera mereka benahi. Para peserta merasa bahwa kemasan memang salah satu hal yang sangat penting dan mereka juga mendapatkan ide-ide baru tentang kemasan yang jauh lebih menarik lagi (Ritonga, 2020).

Setelah melakukan pelatihan, Tim Pengabdian masih melakukan pemantauan dengan terus berkomunikasi terhadap ketua Mitra pengabdian. Kabar yang cukup menggembirakan ialah bahwa ketua Mitra yaitu Ahmad Almaseh menyampaikan bahwa dirinya sudah mulai mencoba untuk merambah pangsa pasar yang lebih luas dengan cara menggunakan inovasi teknologi. Ahmad Almaseh mengatakan bahwa dirinya sudah mulai melakukan penjualan dodol ke daerah Batam. Dengan menggunakan inovasi teknologi, ternyata komunikasi pemasaran lebih efektif dan bisa menopang usaha. Meskipun belum berjalan secara maksimal, tetapi Maseh mengatakan bahwa cara yang demikian cukup membantu bagi usahanya. Harapan selanjutnya ialah bahwa cara-cara yang demikian tidak hanya dilakukan oleh Ahmad Almaseh, tetapi juga dilakukan oleh para pedagang dodol Pasar Bengkel lainnya. 
Berangkat dari contoh kasus yang telah dipraktikkan oleh Ahmad Almaseh di atas, maka jika para pedagang menjalankan prinsip yang disampaikan saat pelatihan tidak menutup kemungkinan bahwa para pedagang produk dodol di Pasar Bengkel akan mengalami peningkatan taraf ekonomi. Penggunaan platform berbasis teknologi informasi menjadi keharusan bagi para pedagang dodol di Pasar Bengkel. Sebab hanya dengan demikian mereka bisa mengembangkan dan memperluas pangsa pasar mereka. Dengan demikian maka pangsa pasar mereka tidak hanya akan tersegmentasi pada pengguna jalan semata. Tetapi bisa merambah ke luar daerah bahkan mancanegara.

\section{SIMPULAN}

Pengabdian Kepada Masyarakat Universitas Sumatera Utara (USU) di Desa Bengkel terkait Pelatihan Strategi Komunikasi Pemasaran Sebagai Upaya Untuk Meningkatkan Pangsa Pasar Produk Dodol di Daerah Pasar Bengkel Kabupaten Serdang Bedagai sangat bermanfaat. Hal ini bisa dibuktikan dengan adanya sikap antusias masyarakat dalam menyambut kegiatan ini. Selain itu para peserta merasa bahwa mereka telah mendapatkan pengetahuan dan paradigma baru dari pelatihan tersebut. Pengetahuan dan paradigma yang mereka peroleh tersebut nantinya akan mereka kembangkan dan praktikkan dalam kegiatan usaha mereka.

Pemahaman dan pengembangan strategi komunikasi pemasaran merupakan salah satu hal yang harus dimiliki oleh para pedagang dodol Pasar Bengkel untuk tetap dapat bertahan dalam menghadapi penurunan pangsa pasar. Bahkan tidak hanya itu, dengan menerapkan strategi komunikasi pemasaran yang berbasis pada inovasi teknologi infomasi, para pedagang bisa saja mendapatkan peningkatan taraf ekonomi yang lebih tinggi dari sebelumnya. Dengan demikian maka para pedagang dodol Pasar Bengkel harus mengubah strategi komunikasi pemasaran dari gaya lama yang lebih konvensional menuju gaya kekinian yang lebih mengandalkan inovasi teknologi informasi.

\section{DAFTAR PUSTAKA}

Dnaberita.com. (2019, June 19). Pusat Oleholeh Pasar Bengkel Perbaungan Ikon Sergai Harus Bangkit. DNA Berita. Retrieved from http://dnaberita.com/2019/06/19/pusatoleh-oleh-pasar-bengkel-perbaunganikon-sergai-harus-bangkit/

Hamid, S. (2016). Analisis Program Pemasaran Produk UMKM Dodol Garut. Jurnal Manajemen Dan Bisnif Kreatif, 2(1).

https://doi.org/https://doi.org/10.36805/m anajemen.v2i1.164

Iriantara, Y. (2014). Manajemen Media Massa. Tangerang Selatan: Universitas Terbuka.

Kuncoro, M. (2007). Ekonomika Industri Indonesia 2007: Menuju Negara Industri Baru 2030. Yogyakarta: CV. Andi.

Morissan. (2015). Periklanan: Komunikasi Pemasaran Terpadu. Jakarta: Kencana Prenada Media Gorup.

Niode, I. Y. (2009). Sektor Umkm Di Indonesia: Profil, Masalah, Dan Strategi Pemberdayaan. Jurnal Kajian Ekonomi Dan Bisnis OIKOS-NOMOS, 2(1). Retrieved from http://repository.ung.ac.id/get/kms/9446/ Jurnal-Sektor-UM-Di-Indonesia-ProfilMasalah-Dan-Strategi-Pemberdayaan.pdf

Rachmawati, F. (2018). Penerapan Digital Marketing Sebagai Strategi Komunikasi Pemasaran Terpadu Produk Usaha Kecil Dan Menengah (UKM) Pahlawan Ekonomi Surabaya. Universitas Islam Negeri Sunan Ampel Surabaya.

Ritonga, A. D. (2020). LPM USU Beri Pelatihan Strategi Komunikasi Pemasaran Bagi Pedagang Pasar Bengkel. Retrieved August 24, 2020, from Kumparan website: https://m.kumparan.com/amp/alwidahlan-ritonga/lpm-usu-beri-pelatihan- 
strategi-komunikasi-pemasaran-bagipedagang-pasar-bengkel-1tsPdutn7Vo

Sudaryanto, Ragimun, \& Wijayanti, R. R. (2013). Strategi Pemberdayaan UMKM Menghadapi Pasar Bebas Asean. Retrieved from https://www.kemenkeu.go.id/sites/default /files/strategi pemberdayaan umkm.pdf

Tusianti, E., Prihatiningsih, D. R., \& Santoso, D. H. (2019). Analisis Hasil SE2016 Lanjutan Potensi Peningkatan Kinerja Usaha Mikro Kecil. Retrieved from https://www.bps.go.id/publication/downl oad.html?nrbvfeve=NjY5MTIwNDhiND c1YjE0MjA1N2Y0MGJI\&xzmn=aHR0c HM6Ly93d3cuYnBzLmdvLmlkL3B1Y mxpY2F0aW9uLzIwMTkvMDMvMDU vNjY5MTIwNDhiNDc1YjE0MjA1N2Y 0MGJIL2FuYWxpc21zLWhhc21sLXNIM jAxNi1sYW5qdXRhbi1wb3RlbnNpLXB lbmluZ2thdGFu 